\section{Time As Asymmetrical and Animal Rights: An Autobiography}

\author{
Daniel A. Dombrowski \\ Seattle University
}

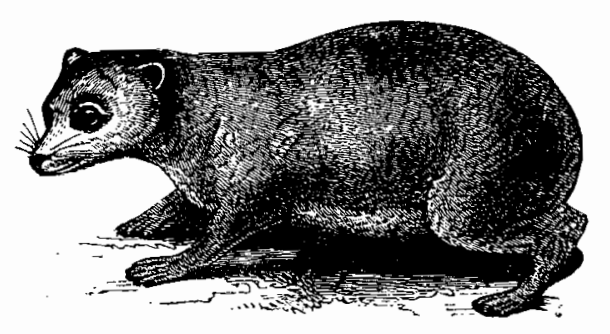

Whenever I have most carefully revised my moral (or philosophical) standards, I am always able to see...that at best I have been finding out, in some new light, the true meaning that was latent in old traditions. ...Revision does not mean mere destruction.

Josiah Royce ${ }^{1}$

Although I am not a Royce scholar, it is this quotation that best sums up my efforts regarding animal rights issues, in particular, and regarding philosophic issues, in general. All of the seemingly non-traditional positions I have at one point or another defended are rooted in the work I have done interpreting traditional sources in the history of Platonism and in the history of religious thought. My views (regarding animal rights, theism, pacifism, ${ }^{2}$ transcendentalism, mysticism, ${ }^{3}$ romanticism) can be referred to as neoclassical. They are "neo" precisely becciuse they are built on a careful consideration of "classical" sources.

Two works of mine illustrate the quotation from Royce with respect to animal rights issues. The first, The Philosophy of Vegetarianism, ${ }^{4}$ is an attempt to rethink the widespread belief that concern for animals

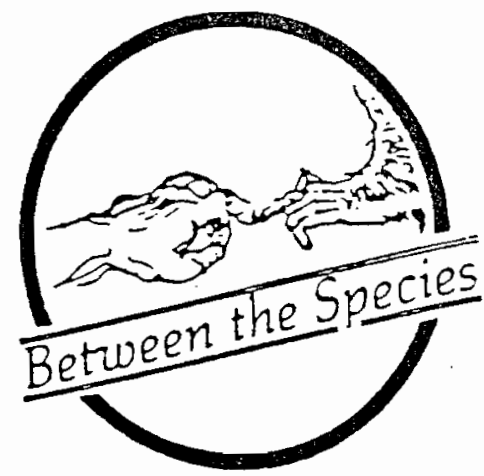

is a recent thing born in the nineteenth century. In fact, I believe that a sizable number of the ancient philosophers were either themselves vegetarian or thought highly of vegetarianism (Pythagoras, Empedocles, Plato, Theophrastus, Seneca, Ovid, Plutarch, Plotinus, Porphyry, etc.). Along with Judith Barad, I think that ancient concern for animals, if not for vegetarianism, lasted well into the medieval period, ${ }^{5}$ although it must be admitted that (Aristotelian) anthropocentrism was not unknown in antiquity, and it was even more prominent in the middle ages than in the ancient period.

Appreciation for the best in the pre-modern world, however, is not the same as anti-modernism. Study of the ancient world, in general, and of ancient attitudes toward animals, in particular, reveals that: (1) the commendable modern concentration on rights, and on the development of liberation movements based on the rights of racial minorities, women, and animals, were not pre-modern phenomena, hence there is a certain superiority to the modern period over the premodern one; and (2) the modern commodification of animals and the view of nature as inert material resource creates exploitation of animals never dreamt of in antiquity. That is, both the ancient and medieval worlds, on the one hand, and the modern and contemporary worlds, on the other, should be taken with several grains of salt.

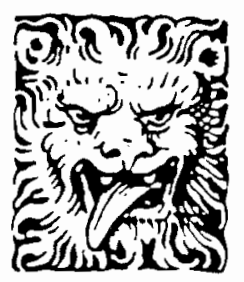

\section{AUTO-}

BIOGRAPHY 
I should note that the title to The Philosophy of Vegetarianism is defective in that it gives no indication of the fact that it is a book about ancient philosophy, but the title does have the virtue (as the editor who suggested the title promised it would) of getting attention for the work. Forty-nine reviews of the book have appeared in journals in any number of disciplines, philosophy, classics, biology, etc., and the book has received awards. Most of these reviews were positive, but even the negative ones pleased me in that, as a defender of Karl Popper's method of bold hypothesis and severe refutation, I found that the attempted refutations made me aware of where, say, my bold views regarding Plato really were strong and where they needed improvement. ${ }^{6}$

The other work that illustrates the quotation from Royce is my Hartshorne and the Metaphysics of Animal Rights. ${ }^{7}$ This book is an attempt to show that animal rightist critiques of anthropocentrism are not only consistent with but are actually required by religious belief, in that such belief indicates some sort of commitment to theocentrism rather than to anthropocentrism. Charles Hartshorne, the focus of this book, provides an excellent example of the connection between theism and anti-anthropocentrism in that he is both one of the great metaphysicians and philosophers of religion in the twentieth century as well as a noted ornithologist. ${ }^{8}$ For too long, theists, including intelligent theists, have made God into something of a tyrant and then imitated this supposed divine tyranny in their own relations with animals. This book is an attempt to rethink these issues.

From the above, one might assume that I was originally led to an animal rights position due to a reading of some classic or other in the history of Greek philosophy or in the history of religion. But this is not the case. I was "converted" to the animal rights movement by the thought of Peter Singer, whom I assume is an atheist or agnostic. I read Animal Liberation one day (literally) in 1979 and saw immediately that his position was correct, although I did not share his utilitarianism. (I am now somewhat less critical of utilitarianism. I should also note that the arguments from sentiency and marginal cases defended by Singer were, as I later discovered, implicit in several Greek thinkers who were obviously not utilitarians.) My present memory of the reading of this book is that I digested all of the steps in all of Singer's arguments in this 297 page book in one gulp. I am obviously hyperbolizing here, but it is nonetheless true that I have never altered my view of any serious matter as quickly and as decisively as I did regarding animal rights (Singer would perhaps say "rights") upon reading Singer's book. He was so obviously correct, I thought, that I should never eat meat nor wear leather again. And I have not.

Autobiographical writings like the present one are obvious occasions for self-deception or puffery. Perhaps historians of philosophy or historians of ideas can mitigate these dangers by keeping in mind that their erudition is always somewhat eclectic and derivative. But it is precisely this eclecticism and derivativeness, I think, that makes history pertinent. Any thinker and writer who is not an outright plagiarist is at least somewhat original, but not even the great thinkers are as original as their epigoni claim. I am convinced that philosophical originality, in general, and originality regarding animal rights issues, in particular, does not so much consist in new elements or conclusions as in the way in which previous elements or conclusions are reticulated, in the way in which the shards from the past--including the recent past-are glued together into a new vessel. There are a finite number of views on even complicated issues, and one's job is to negotiate one's way through the options, under the guidance of previous shipwrecks, to the option that is the best available.

Thomas McFarland overstates the case a bit, but his view is worth consideration:

What, indeed, do we all learn in the course of a scholarly training, but the conventions and gentilities of using other people's thoughts? Sorne we encase in footnotes, some we read, digest, and restate, some we simply regurgitate, but few people in this world, very few indeed, really have more than a genuine idea or two in a lifetime.... We all know many things, but only one or two of those things, or none at all, originates with any one of us. We all stand on the shoulders of others-of our predecessors and of our contemporaries-and we rightly condemn those who attempt to claim more. ${ }^{9}$

Peter Singer is original as an interpreter of Bentham, Mill, Sidgwick, and recent ethicists; Tom Regan is brilliant in his use of Kant, Moore, and recent analytic 
philosophers; etc. Historians of philosophy or historians of ideas are simply more explicit about their status as derivative than thinkers like Singer and Regan, and they are more aware of the fact that the desire for originality itself has a history. It should be noted that the most influential twentieth century philosophers have attempted to wipe the slate clean and to do philosophy from scratch (Moore, Wittgenstein, Russell, Husserl, Heidegger--in a strange way), but it is by no means clear that philosophy has progressed as much as these ahistoricists have predicted it would as a consequence of their mutually exclusive originalities. By way of contrast, I would cite the enormous originality of Whitehead in his self-proclaimed attempts to provide several important footnotes to Plato. ${ }^{10}$

Stephen R. L. Clark would, I assume, agree with the above quotations from Royce and McFarland, but he would incorporate them within a conservative political program wherein enlightenment and universal rights, including animal rights, are criticized. That is, Clark's favorable attitude toward animals arises in a MacIntyre-like way out of familial and parochial attachments, as when he emphasizes the fact that he is concerned primarily with British beasts. ${ }^{11}$ My own liberal, rights-oriented view is that rights themselves are derived from traditional sources, say from the divine concern for individual souls evidenced in medieval thinkers, and perhaps also in ancient ones. Hence, in one sense my views of animals are closer to Clark's than to those of any other thinker in that both of us make claims that are rooted in the history of philosophy and both of us philosophize in a context of religious belief, but in another sense my (historically conditioned) liberalism puts me very much at odds with Clark's conservative thought. It is necessary that we start from some historical condition or other when we think (about animals or about anything else), but the sufficient conditions of any thinker's written work can only be supplied by decisions on the part of the thinker regarding how to react to those historical conditions (including, at times, the decision to reiterate the past in the present).

Thus far I have not indicated very much about my personal life except to say that my views and practices regarding animals were transformed about sixteen years ago. Prior to that I was, naturally enough, born. This event occurred in 1953 in Philadelphia. My roots are in rough, lower middle class (at best) neighborhoods (Frankford, Bridesburg) in a rough city. I doubt if there were very many animal rightists here, if only because the human beings in these neighborhoods lived lives only marginally better than those of animals in our culture. Three of my four grandparents worked fulltime as children, one from the age of eight in various sweat-shops, despite the fact that each of them possessed remarkable natural intelligence. FDR was something of a demigod in our house.

Through heroic efforts on the part on my parents I was (positively) deracinated, to the extent that this is possible, and I learned two crucial lessons: (1) I was loved by them (to this day I am on a regular basis told by people that I seem to be the happiest person they know; make of this what you will); and (2) reading is the only way out of destitution if you are not a great athlete. I was good enough in athletics to be a high school star and a college player but not talented enough to go very far with a professional offer to play in the Mets organization. I have been reading ever since and playing pickup basketball. From athletics I have learned at least this much: defeats (even defeats in the effort to get fair treatment of animals) are not ultimate; in competitive athlein there is always a playful element of desporter. ${ }^{12}$

Three teachers of mine have influenced me most. One was a high school history teacher named Leonard Blostic, who as a Franciscan no doubt prepared the way for my later views regarding animals. A second was Erling Skorpen at the University of Maine, a latter-day Socrates who introduced me to philosophy. And the third was a graduate school teacher named Leonard Eslick, an ethereal Platonist and Whiteheadian who defined "body" as "frozen thought." All three of these have enhanced not only my élan vital but also my zest for the intellectual life, in particular.

Buoyant personalities like mine are always open to the charge of superficiality, in that the suffering that is widespread in the world should, it is alleged, dissuade one from optimism. But, to paraphrase Wordsworth, listening to the sad music of sentient life is not necessarily to despair; it is still possible to urge that "We will grieve not, rather find, strength in what remains behind." In any event, not everyone finds me buoyant and happy; university administrators almost always dislike me, a fact which I wear as a badge of honor.

$I$ do very little that is above and beyond the call of duty regarding animals, say like the supererogatory efforts of Lawrie and Susan Finsen to save strays. But I do perform my duty by not eating, wearing, 
experimenting on,....animals, and I do love to take long hikes in the mountains with "my" mutt Porterhouse. I also enjoy letting the cat into the house from the garage every morning at five (a time which Thoreau describes as "a cheerful invitation to make...life of equal simplicity, and I may say innocence, with Nature"). There is something correct in Clark's critique of the philosophical tendency toward moral abstractions that are not rooted in some concrete familial or communal life. On the one hand, I am at least somewhat moral because I take seriously being a son, brother, husband, father of two (ages fifteen and twenty-one, the latter we adopted when he was ten after a brutal youth), cohabitant with nonhuman animals, and citizen. On the other hand, too much concern for partial affections can lead to narrowmindedness, tendentiousness, or nationalism rather than to universal concern for the rights of sentient creatures. In my own personal case, it is precisely because I was partially deracinated that I was able to escape factory work, at best, or prison, at worst.

Both personal freedom and philosophical originality are, on my view, additions to the definiteness of past reality, ${ }^{13}$ additions that can have the cumulative effect of significant change. Once absolute determinism and absolute freedom are rejected as defensible positions, it is easy to see that a qualified determinism is nothing other than a qualified indeterminism. As before, it is necessary that we work with some past or other in the effort to face the partial indeterminacy of the future. In my own life I have gone from ignorance of animal rights issues (yet a knowledge of Franciscanism) to knowledge of these issues, from knowledge of these issues to a defense of an animal rights stance, from this defense to the confidence that treatment of animal rights issues was intellectually respectable (and this largely due to reading James Rachels and to hearing a paper on zoos by Dale Jamieson), from a personal conviction that a defense of animal rights was intellectually respectable to the not quixotic hope that all rational people will eventually find such a defense convincing. Thinking in long stretches of time very often has its advantages.

Those who think that, or act as if, it is "inevitable" that our future treatment of animals mirror our past treatment of them in effect have adopted a symmetrical view of time: the present's relationship to the future is every bit as determinate as the present's relationship to the past. (Hume, Russell, and some Buddhists seem to have a different, but an equally symmetrical, view: the present's relationship to the past is every bit as indeterminate as its relationship to the future.) My own view is an asymmetrical one, hence the title to this autobiography. We have a determinate relationship to the past in that historical abuses of animals cannot be undone; such abuses force one to admit that human relations with animals will always be tragic for anyone with memory. But the indeterminate relationship we have to the future is not negligible for the simple reason that the future is not here yet to be determined in detail. This indeterminacy should, in the long run, bode well for nonhuman animals.

\section{Notes}

${ }^{1}$ Josiah Royce, The Philosophy of Loyalty (N.Y.: Macmillan, 1908), p. 11.

${ }^{2}$ Christian Pacifism (Philadelphia: Temple University Press, 1991).

${ }^{3}$ John of the Cross: A Contemporary Appreciation (Albany: State University of New York Press, 1992).

${ }^{4}$ The Philosophy of Vegetarianism (Amherst: University of Massachusetts Press, 1984); also published as Vegetarianism (London: Thorsons, 1985), foreword by Peter Singer. Also, see my "Vegetarianism and the Argument from Marginal Cases in Porphyry," Journal of the History of Ideas XLV (March, 1984), pp. 141-143; "Was Plato a Vegetarian?," Apeiron XVIII (June, 1984), pp. 1-9; "Porphyry and Vegetarianism: a Contemporary Philosophical Approach," Aufsteig und Niedergang der Romischen Welt 36.2 (Berlin: De Gruyter, 1987), pp. 774-791; and a review of J.K. Anderson's Hunting in the Ancient World in The Classical Bulletin 62 (Summer, 1986), pp. 51-52.

5 See my "Barad, Aquinas, and From-To Perspective." Between the Species 5 (Winter, 1989), pp. 20-24. Barad's article is in the same issue of this journal.

${ }^{6}$ After The Philosophy of Vegetarianism I refined my treatment of Book Two of the Republic in "Two Vegetarian Puns at Republic 372," Ancient Philosophy 9 (1990), pp. 167-171.

${ }^{7}$ Hartshorne and the Metaphysics of Animal Rights (Albany: State University of New York Press, 1988). Also, see my "Eating and Spiritual Exercises: Food for Thought from Saint Ignatius and Nikos Kazantzakis," Christianity and Literature 34 (1983), pp. 25-32; "The Jesuits and the Zoophilists, Again," Irish Theological Quarterly 51 (1985), pp. 232-241;'Individual, Species, Ecosystems: A Hartshornian View," Between the Species 4 (Winter, 1988), pp. 3-10. 
${ }^{8}$ A good introduction to Hartshorne's thought can be found in his The Divine Relativity (New Haven: Yale University Press, 1948). On his ornithology, see Born to Sing (Bloomington: Indiana University Press, 1973).

${ }^{9}$ Thomas McFarland, Coleridge and the Pantheist Tradition (Oxford: Clarendon Press, 1969), p. 29.

${ }^{10}$ On the relationship between Whitehead and Hartshorne, on the one hand, and Plato, on the other, see my "Hartshorne and Plato," in The Philosophy of Charles Hartshorne, ed. Lewis Hahn (LaSalle, Ill.: Open Court, 1991), pp. 465-488.

${ }^{11}$ See Stephen R. L. Clark, "Utility, Rights and the Domestic Virtues," Between the Species (Fall, 1988), p. 241.

12 See my "Weiss, Sport, and the Greek Ideal," forthcoming in The Philosophy of Paul Weiss (LaSalle, Ill.: Open
Court). On the connection between athletics and irony I owe a great deal to Randolph Feezell, a thinker who has personally influenced me more than any other colleague.

${ }^{13}$ By way of contrast, Heidegger's reactionary view seems to be that "originality" consists in subtraction from the definiteness of past reality. Regarding the dangers of the Heideggerian view, see my "Heidegger's AntiAnthropocentrism," Between the Species (Winter \& Spring, 1994), pp. 26-38. Other works of mine on various aspects of animal rights issues include "Rorty on Pre-Linguistic Awareness in Pigs," Ethics \& Animals 4 (March, 1983), pp. 2-5; "A Dialogue on Philosophical Vegetarianism," APA Newsletter on Teaching Philosophy (Late Autumn, 1984), pp. 8-10; "Thoreau, Sainthood, and Vegetarianism," American Transcendental Quarterly 60 (June, 1986), pp. 25.36; "The Ancient Mariner, God, and Animals," Between the Species 2 (Summer, 1986), pp. 111-115.

\section{Books Received}

Jim Harris and Janice Brungo

EXPRESSING FOR ANIMALS AND THE

EARTH

cassette

$\$ 7.00$

John A. Hoyt

ANIMALS IN PERIL

How "Sustainable Use" is Wiping Out the

World's Wildlife

Garden City Park, NY: Avery Publishing

Group, 1994

foreward, $228 \mathrm{p}$, notes, index

$\$ 10.95$ paper

Brenda Peterson

LIVING BY WATER

True Stories of Nature and Spirit

New York: Ballantine Books, 1994 (1990)

$134 \mathrm{p}$

$\$ 9.00$ paper

Milly Schär-Manzoli (and Max Keller)

HOLOCAUST

ATRA - AG STG, 1994 (1991)

preface, 234p, bibliography

Fr. 20 paper
Bill Schul

LIFE SONG

In Harmony With All Creation

Walpole, NH: Stillpoint Publishing, 1994

foreward, introduction, 201p, bibliography

$\$ 12.95$ paper

\section{SOCIETY \& ANIMALS}

Social Scientific Studies of the Human

Experience of Other Animals

Vol. 2 No. 2, 1994

Cambridge, UK: The White Horse Press, 1994

199 p, books received, index to vols. $1 \& 2$

no price listed

Richard Sylvan \& David Bennett

THE GREENING OF ETHICS

From Anthropocentrism to Deep-Green Theory

Tucson: University of Arizona Press, 1994

preface, $221 \mathrm{p}$, notes, bibliography, index

$\$ 45.00$ cloth, $\$ 22.95$ paper

Jon Wynne-Tyson

ANYTHING WITHIN REASON

Potters Bar, England: Oakroyd Press, 1994

$191 \mathrm{p}$

$£ 14.95$ hardbound 